\title{
Study on the Teaching Reform of College English Course under the Talent Cultivation Mode of Applied Technology
}

\author{
Yuanyuan Zhang, Hua Zhao, Jinlei Huang; \\ China University of Mining and Technology Yinchuan College \\ Jinyou Zhou \\ Shanghai Experimental School
}

\begin{abstract}
Keywords: application of technical personnel; training mode; college English course; teaching reform

Abstract: With the needs of current social development, there is a great demand for the application of skilled personnel. Under such circumstances, the teaching of college English curriculum also needs to be reformed and adjusted on the basis of the original, so as to better cultivate students' practical application ability to bring greater help to the future development of students. This article first analyzes the current situation of college English teaching in our country, and then discusses the reform of college English curriculum teaching with the current actual form.
\end{abstract}

\section{Introduction}

With the change of the current social environment, universities are constantly making reforms in their teaching modes. At present, more and more attention is being given to the cultivation of skilled personnel. As a very important part of college curriculum system, college English curriculum should make corresponding changes in teaching, focus on cultivating students ' practical application ability of English and improving their ability of application . Therefore , more teaching researchers is discussing and researching, hoping to find out more effective teaching methods of college English .

\section{Current Situation of College English Teaching}

College English course belongs to compulsory course of public education in university teaching course system . The main purpose of teaching are to train students ' comprehensive ability of applying English. Since our college English teaching, we have been constantly carrying out reforms to improve students ' ability of listening, speaking, reading, writing in English so that students can master English skills in real life [1] .However, from the current situation of college English teaching in our country, there are still many problems, which mainly include the following: First, part of the teaching of college English courses still use the traditional teaching methods, mainly teaching grammar and words, teachers play a leading role in the teaching process, many students lack of enthusiasm and interest in learning English;Second, teachers only pay attention to the basic knowledge of English to explain the process of teaching, did not create a good atmosphere for students to learn English, many college students do not have the environment to use English , English listening and speaking ability has not been effectively developed, not only detrimental to students interest in learning, but also greatly reduce the effectiveness of English teaching, making the teaching efficiency is very low; Third, lack application opportunities in real life. The main purpose of English teaching are to enable students to apply their knowledge of English in real life . However, at present , many college students only have the opportunity to learn and use English in classes, and have little contact with other times . For a language subject, It will directly affect the students ' practical English application .

\section{Analysis of the Teaching Reform of College English Course under the Talent of Applied Technology Cultivation Mode}

Under the current mode of applying talents training, college English teaching should start to apply 
for cultivating the students ' practical ability, constantly reforming the existing deficiencies in college English teaching, and combining some of their own practical teaching experience , proposed the following teaching reform proposals .

\subsection{Reform Teaching Objectives}

Under the general trend of economic globalization, people have more and more applications of English in real life. As one of the main sources of talent cultivation, universities should pay more attention to English teaching, especially should be clear about the orientation of teaching objectives to cultivate a comprehensive application of technical personnel of strong English communication skills as a target. Therefore, in the teaching of college English, we should pay more attention to improving students ' emphasis on English knowledge learning, and give more college students full attention to college English learning. Secondly, teachers should develop as far as possible from the perspective of cultivating their ability to use English Teaching, so that students have a greater degree of ability in English " Listening and Speaking " [2] ; third, to increase students ' opportunities to actually use English so that students can have more opportunities for classroom teaching applied English knowledge to promote their practical ability ; and finally, students should learning English knowledge with their own major, so that they can quickly enter the job after graduation, and show a strong personal ability [3] .

\subsection{Reform College English Curriculum}

In the current teaching of college English in our country, the teaching of college English mainly starts from two aspects : English reading and writing and English listening and speaking . Combining these two kinds of courses is the cultivation of college students ' English listening , speaking, reading and writing ability. Among the teaching modes, the teaching methods are very simple, and the teaching effects are also very limited, and they are not able to meet the requirements of employing skilled personnel. The teaching of college English in the sett of teaching curricula appropriate reforms should be made [4]. The author of some of their own teaching experience point of view, the implementation of college English courses should be based mainly on the actual situation of student learning, by the students to make their own choice of course, so that most students will be able to maintain a high degree of interest in learning, and can effectively improve the teaching efficiency . For example, the college English teaching can be divided into compulsory courses and elective courses. All students must participate in relevant English knowledge early in the university study, and students should be able to choose their own courses at the later stage : professional English, CET4, English literature and other courses on English [5] . In the early stages of learning, teaching basic English knowledge, the latter should pay more attention to the practical ability of students to enhance the training . Under this teaching mode, students have the initiative to choose the curriculum, they will have a high initiative in learning, and it can better help students to make full use of the knowledge of English, it is more in line with the application of technical personnel training mode .

\subsection{Reform Teaching Mode}

After a large number of practical studies have proved that the traditional college English teaching model on the cultivation of students ' practical ability to have a greater deficit, which requires college English teachers to make the appropriate changes in the current teaching model . First , English teachers should make changes in their thinking. In teaching itself only as a guide, teaching center should be in the student body. In the actual teaching should be good at guiding students to develop students interest in learning English, to encourage students to organize after school and carry out some related English activities, when necessary, give students some help, so as to create a good student English learning environment [6]. Second, English teaching should be enriched in current English teaching. With the rapid development of Internet information technology, there are more resources available in English teaching such as English movies, English music, English lectures, etc . Teachers should flexibly apply these resources and enhance students ' interest in English learning . Finally, the school should set up a special Internet English learning platform for 
the majority of students, so that all English fans can communicate and learn on the platform, so that students have more opportunities after class to apply English knowledge and it also plays an important role in students ' English exercise .

\section{Conclusion}

In summary, with the further development of the teaching reform of college English courses, there are many currently scholars, teachers and experts who have put forward more innovative opinions on the curriculum and teaching modes. The sett of college English curriculum should adapt and meet the trend and demand of social development. The reform of teaching mode should be conducive to the improvement in college English teaching quality and the improvement in students ' language practices ability, and serve the goal of personnel training in applied technology university .

\section{Acknowledgment}

Project Number: Nxsc20160312 Ningxia Hui Autonomous Region higher education innovation and entrepreneurship education reform project:"research based on CFER applied technology of college English curriculum reform "

\section{References}

[1] Li Huanhuan, Niu Xiaojing.Application of technology undergraduate college English curriculum system reform research [J]. Courses Education Research, 2017, (10): 94.

[2] Wang Mingyang.Research on the Reform of College English Teaching Model under the Talent Cultivation Model [J]. Times Education, 2017, (05): 68-69.

[3] Gu Fang. On How to Adapt College English Teaching to Social Development - A Case Study of the Three Gorges University [J]. Examination Weekly, 2017, (51): 85. 